\title{
AGRICULTURAL USE AND WATER QUALITY AT KARSTIC CUBAN WESTERN PLAIN
}

\author{
Juan Reynerio Fagundo Castillo, Patricia González Hernandez
}

\begin{abstract}
In the paper some results of studies on the karstic aquifers of the western plain of Cuba are presented and discussed. The intensive exploitation of these aquifers for agriculture use and drinking water supply induces an increase of marine water intrusion, water salinisation and a progressive increase of chemical corrosion with a greater dissolution of carbonates. During the period of study (1983-1998) a trend in the deterioration of water quality was observed by means of a chronological series of hydrochloride content.
\end{abstract}

KEY WORDS: karts aquifers, marine water intrusion, Cuba

\section{Introduction}

Carbonate aquifers are dynamic geochemical systems in which rock - water interactions occur continuously (Hanshaw and Back, 1980). The belt formed at the mixing of fresh and sea water is the chemically most active part of the system.

The intrusion in the fresh karst water of salt water from the sea causes a mixing process of the two waters, which differ in their chemical and physical behaviour. Among the more significant changes which occur when two waters of different nature are mixed, there are the following: incongruent dissolution of mineral caused by common ion effect, precipitation of ferric minerals caused by the formation of more oxidizing mixture, increase or decrease of the solubility caused by changes in $\mathrm{pH}$, increase of carbonate solubility caused by saline or ionic strength effect, increase of chemical dissolution of carbonates caused by mixing corrosion effect, dolomitization or de-dolomitization and ion exchange processes.

The kinetics and geochemical aspects of the coastal fresh-salt water systems in the particular case of the karstic aquifers at different regions under different climatic conditions were studied: Florida and Yucatan (Back and Hanshaw, 1981; Back et al., 1986; Plummer, 1975); Apulia, Italy (Cotecchia; 1979); Mallorca and Menorca, Spain (Herman, Back and Pomar, 1986); Western Cuba (Arellano et al., 1989, Fagundo et al., 1993; 1996, 1998; Morell et al., 1997 and González et al., 1996; 1998).

In all the above mentioned cases human impact affects both hydro-dynamical processes and calcite dissolution-precipitation processes.

Although apparently slow, these undesirable changes in processes on the karst coastal aquifers have irreversible effects on the water quality used for the plant irrigation and drinking water supply. 
The aim of this paper is to show the rapid changes of water quality and of chemical corrosion processes in the karstic coastal aquifers of western Cuba, caused by human impact.

\section{Geochemichal process in coastal karsic aquifers}

\subsection{Carbonate dissolution-precipitation process}

A detailed explanation of the conditions of saturation, subsaturation and oversaturation with reference to dissolved calcite, and the basis of the changes in the equilibrium of dissolution-precipitation of carbonates were given by Custodio (1986) as a function of the following effects:

a) common ion effect: $\mathrm{Ca}^{+}$contributions to the carbonate dissolution allow a medium, previously saturated with calcite or dolomite, to exceed its solubility product, thus giving rise to carbonate deposits.

b) Ionic change effect: the $\mathrm{Ca}^{+}$and $\mathrm{Mg}^{+}$concentrations affected by clay exchanges originate $\mathrm{Na}^{+}$and other elements. This effect can be appreciated only in slow flow conditions.

c) Ionic strength or saline effect: an increase of the ionic strength $(\mu)$ due the mineralization increase cause a decrease of the calcium ion activity coefficient $(\gamma)$ and an increase of carbonate solubility

$$
\begin{gathered}
\mathrm{Kc}=\gamma_{\mathrm{Ca}} \mu_{\mathrm{Ca}} \gamma_{\mathrm{CO}^{3}} \mu_{\mathrm{CO}^{3}} \\
\mathrm{~K}_{\mathrm{d}}=\gamma_{\mathrm{Ca}} \mu_{\mathrm{Ca}} \gamma_{\mathrm{Mg}} \mu_{\mathrm{Mg}}\left(\gamma_{\left.\mathrm{CO}^{3} \mu_{\mathrm{CO}^{3}}\right)^{2}}\right.
\end{gathered}
$$

d) Temperature changes: temperature affects the dissolution-precipitation equilibrium constants and activities.

e) Mixture of waters with different composition: the mixture of two saturated waters with respect to calcite, both with a different chemical composition, produces a water that can be subsaturated or oversaturated.

The dissolution and precipitation of calcite and dolomite can be summarized in the following equilibrium:

$$
\begin{aligned}
\mathrm{CO}_{2}+\mathrm{H}_{2} \mathrm{O}+\mathrm{CaCO}_{3} & =\mathrm{Ca}^{2+}+2 \mathrm{HCO}_{3}^{-} \\
2 \mathrm{CO}_{2}+2 \mathrm{H}_{2} \mathrm{O}+\mathrm{CaMg}\left(\mathrm{CO}_{3}\right)_{2} & =\mathrm{Ca}^{2+}+\mathrm{Mg}^{2+}+4 \mathrm{HCO}_{3}^{-}
\end{aligned}
$$

The dolomitization can be a common process in a coastal karstic aquifer by the higher $\mathrm{Mg}^{2+}$ contents of the seawater. This process can be written as follows:

$$
2 \mathrm{CaCO}_{3}+\mathrm{Mg}^{2+}=\mathrm{CaMg}\left(\mathrm{CO}_{3}\right)_{2}+\mathrm{Ca}^{2+}
$$

\subsection{Redox process}

There is much reduction-oxidation processes in nature. The oxygen consumption in a karstic aquifer may react with any reduced substance in the aquifer sediment, such as organic matter or $\mathrm{Fe}^{2+}$ bearing minerals like pirite. For the oxidation of orga- 
nic matter can be written:

$$
\mathrm{CH}_{2} \mathrm{O}+\mathrm{O}_{2}=\mathrm{CO}_{2}+\mathrm{H}_{2} \mathrm{O}
$$

The above process increases the dissolution of calcite in natural condition of the aquifer. By human impact (organic waste disposal) this effect is much more emphasised.

Another interesting redox process in coastal karstic aquifers is the sulphate reduction. Sulphate from the sea can be reduced by organic matter by means of biogeochemical process catalysed by anaerobic bacteria of the genus Desulfovibrio (Bitton, 1994) according to the overall reaction:

$$
2 \mathrm{CH}_{2} \mathrm{O}+\mathrm{SO}_{4}{ }^{2-}=2 \mathrm{HCO}_{3}^{-}+\mathrm{H}_{2} \mathrm{~S}
$$

Where: $\mathrm{CH}_{2} \mathrm{O}$ represents the organic matter. The $\mathrm{H}_{2} \mathrm{~S}$ produced can react with the $\mathrm{Fe}^{2+}$-oxides in the sediment and form iron sulphate minerals (Appelo and Postma, 1993). This type of geochemical process is very common at the southern karstic plain of the western of Cuba where lagoons and swamps exist along the coastal line (González et. al., 1998).

\subsection{Adsorption and ion exchange}

Although this process is more common in alluvial aquifers, adsorption and ion exchange occours also in karstic aquifers (Custodio, 1986; Pulido-Bosch et. al., 1993). The reaction can be expressed as:

$$
\mathrm{R} 2 \mathrm{Ca}+2 \mathrm{Na}^{+}=\mathrm{Ca}^{2+}+2 \mathrm{NaR}
$$

Fresh water in coastal terrain is dominated by the $\mathrm{Ca}^{2+}$ and $\mathrm{HCO}_{3}{ }^{-}$ions, as a result of dissolution of calcite, while in sea water, $\mathrm{Na}^{+}$and $\mathrm{Cl}^{-}$are the dominant ions. Sediments in contact with sea water often adsorb $\mathrm{Na}^{+}$for large part (inverse exchange).

\section{Geographical, geological and hydrogeological framework}

Western karstic plain (Fig. 1) is an example of the more widespread morphological landscape throughout the territory. It is developed on Paleocene - Pliocene carbonate terrigenous and transgressive limestone packages. On such sequences there is a Pliocene - Quaternary developed karst, with great capacity and high transmissivity aquifers, with open seaward discharge.

According the karstification degree of the limestone, the transmissivity of the aquifers change from $5000 \mathrm{~m}^{3} / \mathrm{d}$ to $50,000 \mathrm{~m}^{3} / \mathrm{d}$ to. The storage coefficients change from 0.03 to 0.2 . Such high transmission capacity is due to the high primary porosity of the rocks, the increasing of the fracturing and the intense karstification, specially in terms of the accelerated corrosion as a consequence of the mixing of fresh and sea 


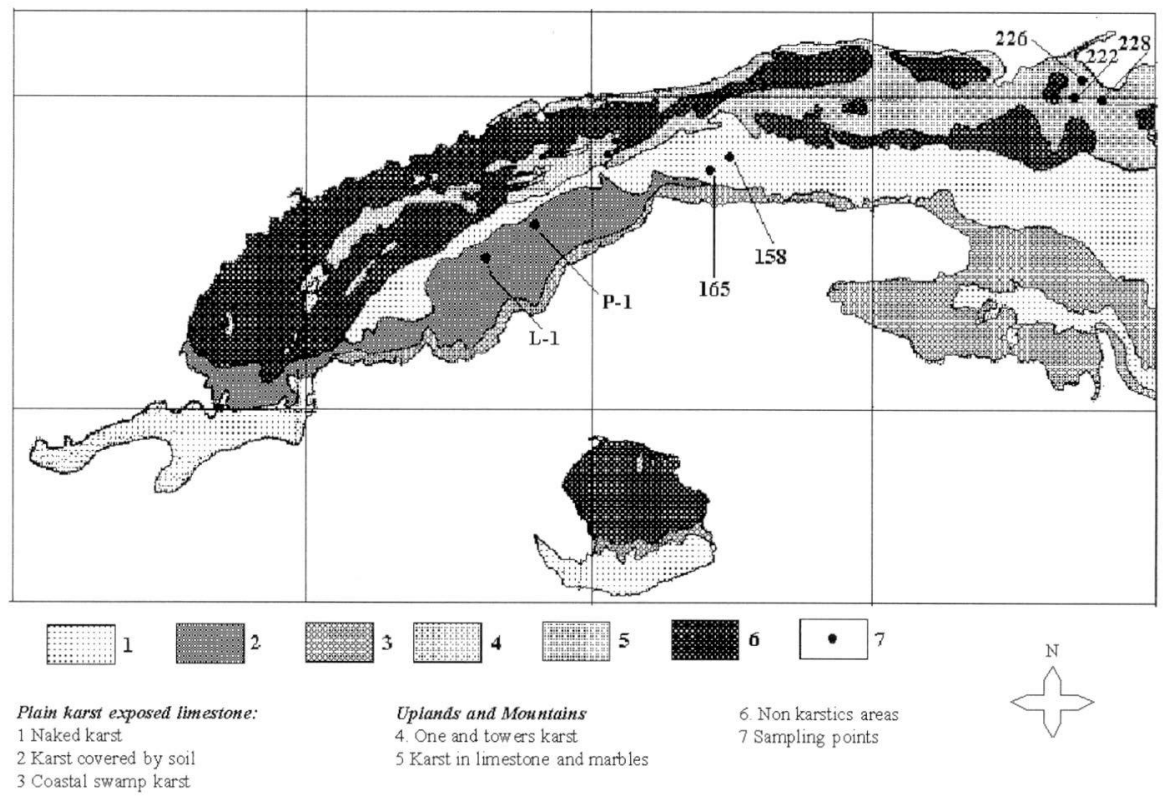

Fig. 1 - Karts areas of Cuban according to Nuñez Iîménez (1984).

waters in the coastal belt. In such aquifers the marine intrusion usually reaches long distance inland.

According to Nunez Jiménez (1984) there are five plain karstic type in Cuba: 1) naked karst, 2) karst covered by soils, 3) littoral karst in marine terraces, 4) thick fluvial and lateritic sediments and 5) coastal swamp karst (Fig.1).

The wells chosen for this study were: Lopez Peña (L-1) and Los Palacios (P-1), at the southern plain of Pinar del Rio Province; P158 and P165 (South Basin of Havana Province), and P224, P225 and P226, at the Varadero-Cardenas hydrogeolocic sector (Matanzas Province), all located at the western portion of the Cuban karstic plain.

\section{Increase of the groundwater salinity in function of agriculture and population water supply demand}

The groundwater extraction for agricultural purpose in some regions of the Cuban karstic plain is of the order of $3.5 \mathrm{~m}^{3} / \mathrm{s}$, while for population supply is of $3.2 \mathrm{~m}^{3} / \mathrm{s}$ (Jiménez et al., 1997).

Table 1 shows the exploitation in the period 1983 - 1995 at the Havana South basin. This territory reach the maximum values of exploitation in $1984\left(188.8 \mathrm{hm}^{3}\right)$ and $1991\left(202.5 \mathrm{hm}^{3}\right)$. The yearly mean precipitation is of $1375 \mathrm{~mm}$, but in the period 1983-1999 the value has been lower. 


\begin{tabular}{|c|c|c|c|c|c|}
\hline Year & $\begin{array}{c}\text { Precipitation } \\
(\mathbf{m m})\end{array}$ & $\begin{array}{c}\text { Exploitation } \\
\left(\mathbf{H m}^{\mathbf{3}}\right)\end{array}$ & Year & $\begin{array}{c}\text { Precipitation } \\
\mathbf{( m m})\end{array}$ & $\begin{array}{c}\text { Exploitation } \\
\left(\mathbf{H m}^{\mathbf{3}}\right)\end{array}$ \\
\hline 1983 & 1961 & 151.8 & 1991 & 1614 & 202.5 \\
\hline 1984 & 983 & 188.8 & 1992 & 1465 & 140.7 \\
\hline 1985 & 1139 & 183.2 & 1993 & 1513 & 129.9 \\
\hline 1986 & 1266 & 192.9 & 1994 & 1270 & 117.3 \\
\hline 1987 & 1141 & 165.9 & 1995 & 1543 & 117.1 \\
\hline 1988 & 1195 & 140.1 & 1996 & 1241 & 106.2 \\
\hline 1989 & & 156.2 & 1997 & 1466 & 107.8 \\
\hline 1990 & 1269 & 164.1 & 1998 & 1064 & \\
\hline
\end{tabular}

Table 1 -Precipitation $(\mathrm{mm})$ and exploitation $\left(\mathrm{hm}^{3}\right)$ at the P165 well (Havana South basin).

As a result of combined effect of the rain deficit and the increasing of water exploitation, the $\mathrm{NaCl}$ contents increased in the groundwater (Fig. 2).

Similar overexploitation with poor precipitation was produced in other places of the plain (Pinar del Río, La Habana and Matanzas).

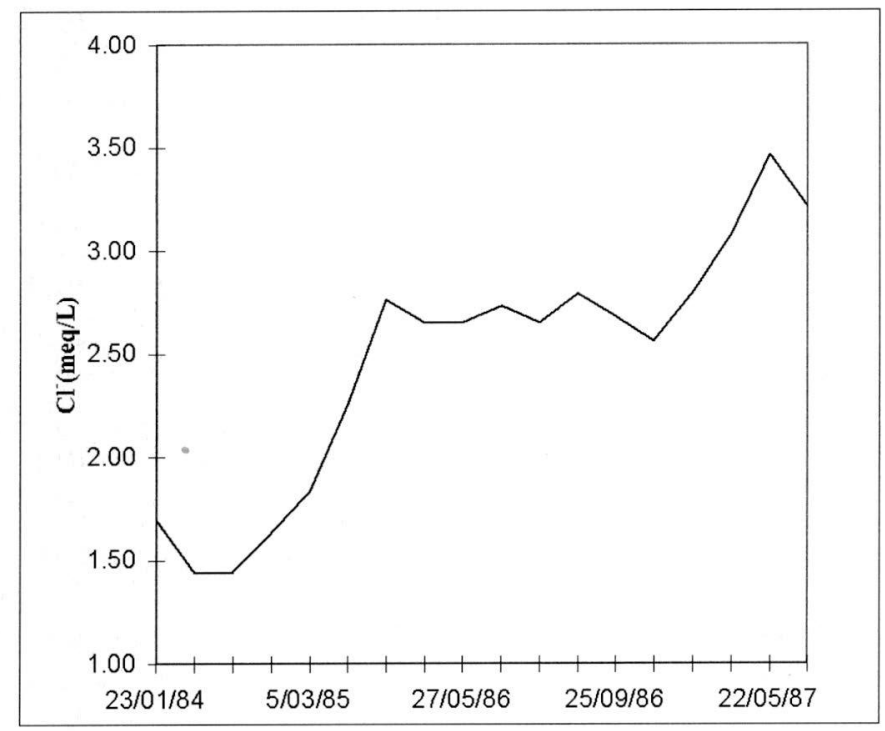

Fig. 2 - Temporal variation of precipitation, exploitation and hydrochloride contents at P165 well (Havana South basin).

\section{Chemical corrosion in the aquifer by mixing fresh and saline waters}

Mixing two waters with different $\mathrm{CO}_{2}$ and ionic contents will result in subsaturation. The renewed aggressiveness in mixed waters may cause calcite dissolution, 
effect which has been called "mischungskorrosion" in German literature (Bögly, 1978).

With the aim to evaluate the effects of mineralization and ion strength $(\mu)$ on the decrease of the calcium ion activity coefficient $(\gamma)$ and increase of carbonate solubility (table 2), a mixture of different proportions (0-100\%) of fresh and sea water was prepared in laboratory. The fresh water came from the Jaruco-Aguacate basin, located at great distance from the coast, in an aquifer developed on Miocene limestone. The sea water was sampled in the Atlantic Ocean.

\begin{tabular}{|c|c|c|c|c|c|c|c|c|c|c|c|}
\hline Sea water $(\%)$ & 0 & 1 & 2 & 3 & 4 & 5 & 6 & 7 & 8 & 9 & 10 \\
\hline \multicolumn{12}{|l|}{ Study ions } \\
\hline $\mathrm{HCO}_{3}{ }^{-}(\mathrm{mg} / \mathrm{L})$ & 270 & 266 & 268 & 260 & 258 & 255 & 250 & 246 & 252 & 248 & 252 \\
\hline $\mathrm{Cl}^{-} \quad(\mathrm{mg} / \mathrm{L})$ & 17 & 200 & 389 & 568 & 761 & 938 & 1120 & 1314 & 1498 & 1680 & 1863 \\
\hline $\mathrm{SO}_{4}^{2-}(\mathrm{mg} / \mathrm{L})$ & 12 & 34 & 66 & 83 & 111 & 140 & 159 & 196 & 214 & 246 & 262 \\
\hline $\mathrm{Ca}^{2+}(\mathrm{mg} / \mathrm{L})$ & 60 & 66 & 69 & 72 & 74 & 79 & 84 & 86 & 89 & 92 & 96 \\
\hline $\mathrm{Mg}^{2+}(\mathrm{mg} / \mathrm{L})$ & 15 & 32 & 41 & 52 & 66 & 73 & 89 & 101 & 115 & 123 & 139 \\
\hline $\mathrm{Na}^{+} \quad(\mathrm{mg} / \mathrm{L})$ & 13 & 118 & 220 & 320 & 426 & 525 & 632 & 728 & 835 & 938 & 1042 \\
\hline $\mathrm{K}^{+} \quad(\mathrm{m} g / \mathrm{L})$ & 1 & 5 & 8 & 12 & 16 & 21 & 24 & 28 & 31 & 35 & 39 \\
\hline $\mathrm{EC}(\mu \mathrm{S} / \mathrm{cm})$ & 553 & 1230 & 1850 & 2596 & 3306 & 3850 & 4470 & 5080 & 5672 & 6270 & 6850 \\
\hline$\gamma \mathrm{Ca}^{2+}$ & 0.71 & 0.64 & 0.60 & 0.57 & 0.54 & 0.52 & 0.50 & 0.48 & 0.47 & 0.46 & 0.44 \\
\hline$\gamma \mathrm{HCO}_{3}^{-}$ & 0.92 & 0.89 & 0.87 & 0.86 & 0.85 & 0.84 & 0.83 & 0.82 & 0.81 & 0.81 & 0.80 \\
\hline TSS $\quad(\mathrm{mg} / \mathrm{L})$ & 388 & 721 & 1061 & 1367 & 1712 & 2031 & 2358 & 2699 & 3034 & 3362 & 3693 \\
\hline$\sqrt{\mu}$ & 0.08 & 0.12 & 0.14 & 0.16 & 0.18 & 0.20 & 0.21 & 0.23 & 0.24 & 0.25 & 0.27 \\
\hline
\end{tabular}

Table 2 - Ion concentrations, electric conductivity (EC), total soluble solids (TSS), ion activity coefficients and square roof of the ion strength $(\mu)$ at a fresh water (Jaruco Aguacate basin) and at different proportions of seawater mixture (Atlantic Ocean).

The ions contents (in terms of TSS and EC) increase with the percent of see water in the mixture, while hydrocarbonate $\left(\gamma \mathrm{HCO}_{3}{ }^{-}\right)$and calcium $\left(\gamma \mathrm{Ca}^{2+}\right)$ activity coefficients decrease. The chemical corrosion $\left(\left[\mathrm{Ca}^{2+}\right]_{\mathrm{chc}}\right)$ in terms of calcium $(\mathrm{mg} / \mathrm{l}) \mathrm{remo}-$ ved from the aquifer by the waters has been calculated by the following equation:

$$
\left[\mathrm{Ca}^{2+}\right]_{\mathrm{chc}}=\left[\mathrm{Ca}^{2+}\right]_{\mathrm{s}}-\left[\mathrm{Ca}^{2+}\right]_{\mathrm{m}}
$$

Where:

$\left[\mathrm{Ca}^{2+}\right]_{s}$ : Calcium contents determined with analytical methods

$\left[\mathrm{Ca}^{2+}\right]_{\mathrm{m}}$ : Calcium contents calculated from the conservative mixture.

The above parameters have been calculated using the relationships between the hydrochloride contents and the fresh water percent in the mixture $\left(\mathrm{P}_{\mathrm{m}}\right)$, as well as the 
calcium contents relationships. The resulting equation is the following:

$$
\mathrm{P}_{\mathrm{m}}=0.1812\left[\mathrm{Cl}^{-}\right]_{\mathrm{S}}-0.09
$$

Where $\left[\mathrm{Cl}^{-}\right]_{\mathrm{S}}$ is the hydrocloride concentration of the sample (mg/l). The slop represents the $\mathrm{Cl}^{-}$concentration at the 0 percent of the mixture and the intercept is the $\mathrm{Cl}^{-}$contents of the groundwater without salinization. Then, the calcium contents supplied for the mixture $\left[\mathrm{Ca}^{2+}\right]_{\mathrm{m}}$ is:

$$
\left[\mathrm{Ca}^{2+}\right]_{\mathrm{m}}=0.2 \mathrm{P}_{\mathrm{m}}+3.0
$$

Which can be calculated as a function of the mixture percent from the corresponding relationships (table 1). Combining (1), (2) and (3) the equation can be written:

$$
\left[\mathrm{Ca}^{2+}\right]_{\mathrm{chc}}=\left[\mathrm{Ca}^{2+}\right]_{\mathrm{s}}-0.03824\left(\mathrm{Cl}^{-}\right)+2.982
$$

The $\left[\mathrm{Ca}^{2+}\right]_{\mathrm{chc}}$ values can be expressed in terms of $\mathrm{CaCO}_{3}$ hardness $(\mathrm{mg} / \mathrm{l})$ as the following:

$$
\left[\mathrm{CaCO}_{3}\right]_{\mathrm{chc}}=50\left[\mathrm{Ca}^{2+}\right]_{\mathrm{chc}}
$$

This magnitude can be used to compare the corrosion developed in the different sites of the basin or in the aquifers located in different places.

With the aim to test the above calculations two pairs of wells from different aquifers representative of waters with lower and higher salinity in the same basin at Pinar del Rio, Havana and Matanzas Provinces were chosen. The different behaviour of the wells is due to the local differences of the limestones composition, porosity and fissuration, to the location with respect to the coastal line and to the degree of water extraction for agricultural and population supply purpose. In the following tables (3$5)$, the mixture percent $\left(\mathrm{P}_{\mathrm{m}} \%\right)$ and the chemical corrosion $\left(\left[\mathrm{CaCO}_{3}\right]_{\mathrm{chc}}, \mathrm{mg} / \mathrm{l}\right)$ are shown for the studied period in the karstic aquifer open to sea at Pinar del Rio, Havana and Matanzas Provinces respectively.

In general, the quantities of $\mathrm{CaCO}_{3}$ removed from the limestones in the three studied places of the western Cuban karstic plain are different, and a major increase of the chemical corrosion can be appreciate in those aquifers which have larger percent of sea water.

While the quantity of $\mathrm{CaCO}_{3}$ removed from the limestone is similar in the Pinar del Rio and Matanzas wells, it doubles in the Havana karst, maybe due to the different lithological and tectonic characteristics of the aquifers.

The different $\mathrm{CaCO}_{3}$ magnitudes in the Havana aquifers and in the Pinar del Rio Province aquifers can be related with the different nature of their catchment areas. In Havana area the runoff comes directly from precipitations, and the $\mathrm{CaCO}_{3}$ is dissolved in an open system (with free $\mathrm{CO}_{2}$ ), while in the area of Pinar del Rio the aqui- 


\begin{tabular}{|c|c|c|c|c|c|c|}
\hline \multirow[b]{2}{*}{ year } & \multicolumn{3}{|c|}{ L-1 } & \multicolumn{3}{|c|}{ P-1 } \\
\hline & $\mathbf{N}$ & $\mathbf{P}_{\mathrm{m}}$ & $\begin{array}{c}\mathrm{CaCO}_{3} \mathrm{cq} \\
(\mathrm{mg} / \mathrm{L})\end{array}$ & $\mathbf{N}$ & $\mathbf{P}_{m}$ & $\begin{array}{c}\mathrm{CaCO}_{3} \mathrm{cq} \\
(\mathrm{mg} / \mathrm{L})\end{array}$ \\
\hline 1974 & 1 & 0.07 & 24 & & & \\
\hline 1975 & 5 & 0.10 & 21 & & & \\
\hline 1976 & 5 & 0.02 & 17 & 5 & 0.70 & 69 \\
\hline 1977 & & & & 11 & 0.69 & 53 \\
\hline 1978 & & & & 8 & 0.69 & 61 \\
\hline 1979 & 1 & 0.03 & 40 & & & \\
\hline 1980 & 1 & 0.01 & 47 & & & \\
\hline 1982 & 3 & 0.03 & 41 & 9 & 0.85 & 71 \\
\hline 1983 & 7 & 0.03 & 36 & 8 & 0.87 & 66 \\
\hline 1984 & 7 & 0.04 & 33 & 2 & 1.04 & 57 \\
\hline 1985 & 7 & 0.03 & 33 & 2 & 1.04 & 59 \\
\hline 1986 & 4 & 0.03 & 41 & 2 & 1.02 & 86 \\
\hline 1987 & 3 & 0.03 & 32 & 2 & 1.16 & 99 \\
\hline 1988 & 1 & 0.03 & 28 & 2 & 1.16 & 90 \\
\hline $\begin{array}{l}\text { Mean } \\
\text { value }\end{array}$ & & 0.04 & 32 & & 0.81 & 66 \\
\hline
\end{tabular}

Table 3. Mixture percent and chemical corrosion magnitude at the Pinar del Rìo southern karstic plain.

\begin{tabular}{|c|c|c|c|c|c|c|}
\hline & \multicolumn{3}{|c|}{ Pozo 158 } & \multicolumn{3}{c|}{ Pozo 165 } \\
\hline year & $\mathbf{N}$ & $\mathbf{P}_{\mathbf{m}}$ & $\begin{array}{c}\mathbf{C a C O}_{3} \mathbf{c q} \\
(\mathbf{m g} / \mathrm{L})\end{array}$ & $\mathbf{N}$ & $\mathbf{P}_{\mathbf{m}}$ & $\begin{array}{c}\mathbf{C a C O}_{3} \mathbf{c q} \\
(\mathbf{m g} / \mathrm{L})\end{array}$ \\
\hline 1984 & 6 & 0.06 & 78 & 4 & 0.21 & 67 \\
\hline 1985 & 4 & 0.08 & 80 & 2 & 0.30 & 92 \\
\hline 1986 & 10 & 0.11 & 88 & 9 & 0.43 & 85 \\
\hline 1987 & & & & 3 & 0.53 & 145 \\
\hline $\begin{array}{c}\text { Mean } \\
\text { value }\end{array}$ & & 0.09 & 83 & & 0.38 & 92 \\
\hline
\end{tabular}

Table 4. Mixture percent and chemical corrosion magnitude at the Havana southern karstic plain 


\begin{tabular}{|c|c|c|c|}
\hline & \multicolumn{3}{|c|}{ Pozo 222 } \\
\hline year & $\mathbf{N}$ & $\mathbf{P}_{\mathbf{m}}$ & $\begin{array}{c}\mathbf{C a C O}_{\mathbf{3}} \mathbf{c q} \\
(\mathbf{m g} / \mathbf{L})\end{array}$ \\
\hline 1983 & 2 & 1.21 & 53 \\
\hline 1984 & & & \\
\hline 1985 & & & \\
\hline 1986 & & & 133 \\
\hline 1987 & 3 & 6.34 & 82 \\
\hline 1988 & 1 & 7.79 & 118 \\
\hline 1989 & 1 & 3.95 & 215 \\
\hline 1990 & 4 & 5.26 & 133 \\
\hline $\begin{array}{c}\text { Mean } \\
\text { value }\end{array}$ & & 4.18 & \\
\hline
\end{tabular}

Table 5. Mixture percent and chemical corrosion magnitude at the hydrogeologic sector of Varadero-Cardenas (Matanzas Province)

fers are confined and the $\mathrm{CaCO}_{3}$ is dissolved in a closed system with respect to $\mathrm{CO}_{2}$. The low values obtained at Matanzas where the aquifers are also open to the precipitations, as Havana, can be explained referring to the different characteristics of the limestone, that, in Cardenas - Varadero sector of Matanzas, is very dolomitized. The dissolution of dolomite at the groundwater temperature of $\mathrm{Cuba}\left(25^{\circ} \mathrm{C}\right)$ is lower than that of the pure limestone.

The additional role of the $\mathrm{CO}_{2}$ contents in the chemical corrosion can be illustrated by the example of the P222 well at the Varadero-Cardenas hydrogeologic sector (table 6). In this place, a sugar cane factory spills its wastes directly through a ponor into the karst and therefore $\mathrm{CO}_{2}$ contents are high.

The kinetics experiment carried out in laboratory (Table 7), are coherent with the water underground behaviour.

\begin{tabular}{|l|c|c|c|}
\hline & POZO & $\mathbf{N}$ & $\mathrm{CaCO}_{3} \mathbf{c q}(\mathbf{m g} / \mathbf{L})$ \\
\hline $\begin{array}{l}\text { Pinar del } \\
\text { Río }\end{array}$ & L-1 & 15 & 30 \\
\hline Habana & 158 & 7 & 69 \\
\hline Matanzas & 226 & 7 & 30 \\
\hline
\end{tabular}

Table 6. Relation among the basical chemical corrosion removed from selected places at the Pinar del Rio, Habana and Matanzas Provinces with a mixture percent on the order of 0.04-0.05\%.

\begin{tabular}{|c|c|}
\hline 0 & 0 \\
\hline 2 & 144 \\
\hline 6 & 269 \\
\hline 10 & 344 \\
\hline
\end{tabular}

Table 7. Variation of the chemical corrosion in the interaction $\mathrm{CO}_{2}-\mathrm{H}_{2} \mathrm{O}-\mathrm{CaCO}_{3}$ with different percent of $\mathrm{NaCl}$ in the water. 
The results discussed above allow to realize how drastic are the changes resulting from human impact in the karstic coastal acquifers of Cuba. These changes bring both to water quality deterioration and to increasing of secondary porosity of the carbonates, especially as a result of the aquifer overexploitation and of the organic wastes spill.

\section{Conclusions}

By means of the study of chronological series of hydrochloride contents, significant differences of the magnitude of chemical corrosion in the karstic coastal aquifers of western Cuban were found. The aquifers show an intense chemical corrosion, which is function of the sea water percent in the mixture and of different types of human impact. These aquifers are submitted to great exploitation for agricultural and water supply purpose, and occasionally are affected by the sugar cane waste spill.

\section{REFERENCES}

APPELO C.A.J., D. POSTMA, 1993. Geochemistry, groundwater and poilution. Balkema Ed., Rotterdam, Brookfield.

ARELLANO D. M., FAGUNDO J.R., JILEK P., SILAR J., 1989. Radiocarbon dating in a karstified coastal aquifer in Cuba. Acta Universitatis Carolinae - Geologica. Ed. Univ. Karlova (Praga) 3: 367-387.

BACK W., HANSHAW B.B., 1981. Comparison of chemical hydrology of the carbonate peninsulas of Florida and Yucatan. Journal of Hydrology, Vol. 10 (4): 330-368.

BACK W., HANSHAW B.B., HERMAN J.S., VAN DRIEL J.N., 1986. Differential dissolution of a Pleistocene reef in the ground water mixing zone of coastal Yucatan, Mexico. Geology, 14: 137-140.

BÖGLY A., 1978. Corrosion by mixing karst water. Trans. Cave Res. Group G. Brit., 13 (2): 109-114.

COTECCHIA et al., 1975. Geochimica delle acqua soterranee della Peninsola Salentina in relazione al rapporte tra le acque di falda, le acque marine sotterranee e il mare. Geologia Applicata e Idrogeologia, X (1): 205-224.

CUSTODIO E., 1986. Hidroquímica del Karst. Jornada sobre el karst en Euskadi, Sn. Sebastian, Espana: 131-139.

FAGUNDO J.R., ARELLANO D.M., 1991. Hydogeochemical impacts of coastal karst aquifer overdrafts. Studia Carsologica, 5: 37-47.

FAGUNDO J.R., ARELLANO D.M., BENITEZ G., SURI A., AVILE C., FERRERA V., TORRES Y M., 1993. Cambios hidrogeoquImicos por sobreexplotacion de aculferos carsicos. Libro de Comunicaciones. I Taller sobre Cuencas Experimentales en el Karst, Matanzas (Cuba), 1992. Univ. Jaume I, Castellon (Espana), 141-148.

FAGUNDO J.R, VALDES J.J., RODRIGUEZ J.E., 1996. Hidroquİmica del Karst. Universidad de Granada.

GONZALEZ P., FERRERA V., BENITEZ G., FAGUNDO J.R., SANCHEZ L., 1996. Estudios experimentales de disolucion de rocas carbonatadas en condiciones de mezcla agua dulce-agua de mar. In Fagundo Castillo J.R., PErez Franco D., Alvarez Nodarse A., GarcIa J.M., Morell I. (ed.), Contribuciones a la hidrogeologìa y medio ambiente en Cuba. Universidad de Castellon (Espana), 357-366.

GONZALEZ P., FAGUNDO J.R., BENITEZ G., SUAREZ M., RAMIREZ J., 1998. 
Influencia de la reduccion de sulfatos en los procesos de disolucion y precipitacion de carbonatos en un acuifero carsico costeroi. In Memorias del XII Seminario Internacional del CIRA y XII Seminario Internacional sobre Gestion y TecnologÌa de Suministro de Agua Potable y Saneamiento Ambiental. ISPJAE, La Habana.

HANSHAW B.B., BLACK W., 1980. Chemical mass-wasting of the northern Yucatan Peninsula by groundwater dissolution, Geology: 222-224.

HERMAN J.S., BACK W., POMAR L., 1986. Speleogenesis in groundwater mixing zone. The coastal carbonate aquifers of Mallorca and Menorca, Spain. 9th Congreso Internacional de EspeleologÌa, Barcelona, 1: 13-1.

JIMENEZ S., SANTIESTEBAN E.R., ARENCIBIA J.A., 1997. Evolucion de la intrusion marina en el acuifero de la costera Sur de La Habana. In Arellano D.M., Gumez-Martin M.A., Antiguedad I. (ed.), Investigaciones Hidrogeologicas en Cuba., Bilbao, 115-123.

MORELL I., GIMENEZ E., FAGUNDO J.R., PULIDO-BOSCH A., LOPEZ-CHICANO M.L., CALVACHE M.L., RODRIGUEZ J.E., 1997. Hydrogeochemistry and karstification in the Cienaga de Zapata aquifer (Matanzas, Cuba).In Gunay, Johnson (ed.), Karst Water and Environmental Impacts, Balkema, Rotterdam, Brookfield, 191-198.

NUNEZ JMENEZ A., (ed.) 1984. Cuevas y Carsos. La Habana.

PLUMMER L.N., 1975. Mixing of seawater with CaCO3 groundwaters. Geol. Soc. Am. Mem., 142: 219-236 